\title{
Communism by the Letter: Doris Lessing and the Politics of Writing
}

As one of many writers and intellectuals who became a Communist, then left the Party to become its unrelenting and severe critic, Doris Lessing in some respects followed a very familiar narrative. Literary Communism is most closely associated with writers of the 1930s 'Red Decade' generation, and has often been thought of as a naive and youthful aberration, to be followed inevitably by profound disillusionment and then repentance coupled to a militant Cold War liberalism. This familiar narrative of 'the journey into Communism, and the return' was influentially cemented by the six contributors to Richard Crossman's edited collection The God that Failed (1949), as well as in the subsequent historiography surrounding the 'Auden gang'. ${ }^{1}$ This narrative has been a sustaining myth of the literary Cold War, underpinning a heavily polarised understanding of political commitment. On the one hand, by their own testimony, those writers experienced the turn to Communism as a religious conversion and described 'mental rapture which only the convert knows. ${ }^{2}$ On the other hand, as apostates, they embraced anti-Communism with a similar fervour. 'Ex-Communists', wrote Hannah Arendt in an essay of that name, 'are not former Communists, they are Communists "turned upside down", replacing one dogmatism for another. ${ }^{3}$ Lessing's antiCommunism did at times tilt into paranoia. However, her early engagement with Communism was not the all-consuming infatuation described by Arthur Koestler, for example. Before and during her membership of the Party, she expressed and debated views that went far beyond its official orthodoxy. Lessing was a member of the Communist Party of Great Britain from 1952 to 1956, but her involvement with Communist politics began earlier, in Southern Rhodesia (now Zimbabwe). Her engagement with Communism is a well-known element of her early formation but this paper draws on archival materials that enable us to reconstruct the early phase of Lessing's intellectual development in greater detail. These 
archives are relatively recently opened and are only beginning to be consulted by Lessing scholars. In helping us to paint a more detailed and complex picture of her early career, these materials provide a vital and (to date) untapped resource for understanding Lessing's early political and aesthetic formation, without simply assimilating it to the pattern of the $1930 \mathrm{~s}$ Communist converts. With that in mind, this paper pursues two related goals.

Firstly, I aim to reposition Lessing politically, in relation to the currents of the midcentury far left, setting out a nuanced picture of Lessing's early political development. In the second volume of her autobiography, Walking in the Shade (1997), she described her decision to join the CPGB in 1952 as 'probably the most neurotic act of my life', emphasising that she already had severe doubts about the Party. ${ }^{4}$ The word 'neurotic' captures some of the complexity of Lessing's position (as well as being one Koestler applied to his Communist period) — she had given up unthinking loyalty to Stalin's Soviet Union before she moved to England in 1949. Yet Lessing did not become a Communist by mistake. The archival materials which I draw on below_predominantly letters in recently opened archives held at the University of East Anglia and the University of Sussex-provide a more ambivalent picture of a rational and skeptical individual who gravitated towards Communism with her eyes open. They also show that many of the intellectual disputes that led to Lessing's departure in 1956, and the formation of the New Left, were already in place before she arrived in London.

Secondly, I aim to throw light on the early development of Lessing's thinking about realism and the novel (mostly known through her famous essay 'The Small Personal Voice') and on her novelistic practice as she reflected on her experiences in the Party in her fiction up to and including Landlocked (1965). Lessing grappled with Marxist literary theory in the 1940s and took some striking positions that shed light on her later arguments and novelistic practice. She anticipated and sought to circumvent the Cold War opposition between realism 
and modernism and asserted a place for artistic autonomy. Her letters also demonstrate her growing interest in Communist language - the approved vocabulary of Party discourse, and its characteristic argumentative style. I explore how Lessing took that interest in Communism's linguistic community into her fiction and suggest that this played a pivotal role in her investigation of her major theme, 'the individual conscience in its relations with the collective'. ${ }^{5}$

\section{$\underline{\text { Lessing and Commitment }}$}

Arguably the most important documents in Lessing's recently opened archives are the numerous letters (over 200 in total) written mainly between 1944 and 1949, to three RAF servicemen Lessing met in Southern Rhodesia (now Zimbabwe) during the war: John Whitehorn, Coll MacDonald and Leonard Smith (known as Smithie). These three men are fictionalised in the African section of The Golden Notebook (1962) as, respectively, Paul, Jimmy and Ted. '[W]e were all, at various times, in love with each other', writes Anna in The Golden Notebook. ${ }^{6}$ Lessing's affairs with John and Smithie are documented in the letters, against the background of her sexually fraught marriage to the ideologically doctrinaire, jealous Gottfried Lessing. There is less evidence of a sexual relationship with Coll, though she does remark that 'I love you all in undivided one-third shares'. ${ }^{7}$ She signed her correspondence 'Tigger', the nickname by which they all knew her. All three men had been at Cambridge University - the 'Cambridge RAF', she calls them in her autobiography — and Lessing, unusual among Nobel prizewinners in that she did not attend university, drew them into a sort of ongoing seminar by post, discussing literature, politics, history and current affairs, and exchanging books. ${ }^{8}$ They had all been members of the Left Club, Lessing's Communist 'group' in Salisbury (now Harare): there was no recognised Party in the colony at 
that time. The letters reflect on the developing geopolitical situation from the inside of an intellectual and independent-minded Communist grouping, showing the transition from the wartime alliance which united the RAF with the USSR in the fight against fascism, to the early stages of the Cold War.

Lessing's initial movement towards Communism was in part influenced by the racial politics of Southern Rhodesia. The racism of the colonial system extended well beyond governmental institutions and permeated much of civil society, including the traditional, trade unionist left. Lessing wrote that ' $[\mathrm{t}]$ he white trade union movement is thus in the Union [of South Africa] and in Rhodesia, paradoxically enough, the most reactionary force there is, and the strongest factor against the breaking down of the colour bar.' ${ }^{9}$ Continuing her reflections on trade union politics, she argues that 'it will be a very long time before any one will support an African getting even half as much as a white man. (Outside the extreme left.) ${ }^{10}$ In The Golden Notebook, Anna Wulf writes in her black notebook: 'I became 'a communist' because the left people were the only people in the town with any kind of moral energy, the only people who took it for granted that the colour bar was monstrous' ${ }^{11}$ It is the assumption of everything Lessing wrote on the subject that in Southern Rhodesia in the 1940s a dedicated anti-racist had nowhere else to go but to Communism.

Lessing's Communism was not only an answer to the racism of the colony, and Marxism became for a time an all-embracing world view. However, by the time the surviving letters to John, Coll and Smithy begin in 1944, any ardent infatuation with Communism was already in the past. As early as 1945-in a letter written to John Whitehorn on V-J day—she reflects critically and somewhat ironically on her route into Communism:

At this stage I meet [a] group of communists, filled with Marxist theories and dialectics, and in the space of a few months absorb the lot, everything falls into a beautiful pattern 
and all one's rather arid open-mindedness vanishes while one falls not only in love with several communists but communism in general.

But the best of all is the way that everything can be explained in terms of the class struggle. This state lasts for various lengths of time, in some people I suppose for ever, but in me for about a year. I don't expect I have ever been so happy in my life as during this time. ${ }^{12}$

This happy state is reflected in a fictionalised version of this period of her life, A Ripple from the Storm (1958), the third instalment of the Children of Violence series. Lessing describes Martha Quest, her fictional alter-ego, in a 'condition of joy and release', intoxicated by the words of Anton Hesse, the leader of her small Communist group (based on her husband Gottfried Lessing), as he gives a lecture on Marxism: 'She was feeling a comprehensive compassion: for the pitiful past, and for the innumerable happy people of the world whom she was pledging herself to deliver. ${ }^{, 13}$ In this novel, written after she left the Party, the warm satisfaction that can be derived from a comprehensive Marxist analysis is frequently undercut by irony. By 1945, this letter to John shows that the sense of an untainted satisfaction had already receded into memory, and Lessing's continuing attachment to Communism was shot through with moral dilemmas and a sense of compromise. She wavered between a state of moral crisis about the fate of Communism in the Soviet Union, and a pragmatic acceptance of the Party line. Though Lessing would not formally join the Communist Party until 1952, nor leave it until 1956, the letters show how and why she moved away from an unqualified commitment to the cause by 1945 .

\section{$\underline{\text { Marxism and Literature }}$}


During the late 1940s as she conducted her correspondence with the Cambridge RAF, Lessing was working on the manuscript of The Grass is Singing (1950). As both an active Communist and an aspiring novelist, Lessing was concerned in this period with the Communist approach to literature, and the growing tension between a Soviet-sanctioned socialist realism and a Western canon of modernist writing. In her letters of the 1940s she describes reading Joyce, Proust, Woolf and Kafka, and grapples with questions about the relationship between aesthetic autonomy and political commitment. These letters provide an invaluable supplement to Adam Guy's compelling analysis of Lessing's 'The Small Personal Voice' (1957) and 'A Letter from Home' (1963) — helping to provide a 1940s background to Guy's question of 'how Lessing begins to think about commitment'. ${ }^{14}$

This is particularly evident in her response to the so-called 'Soviet Literary Controversy' of 1946, a cultural purge within the Soviet Union, led by Zhdanov and intended to produce a new ideological orthodoxy in Communist literature. The most celebrated targets of the purge were the popular and humorous writer Mikhail Zoschenko and the poet Anna Akhmatova, who were denounced in literary periodicals and on the front page of Pravda. As well as these two prominent figures, the purge took aim at a number of literary periodicals which were deemed to be promoting the wrong kinds of writing. Ben Harker has recently explored the ways in which the Controversy was debated amongst the British left, including J.B. Priestley, Cyril Connolly and Raymond Williams. Harker argues that the Controversy should be seen as 'a significant location in the unmaking of the cultural formations of the 1930s' and, he writes 'a formative, if now largely forgotten, site in the emergence of a Cold War cultural politics better known via 'anti-Communist' fiction'. ${ }^{15}$ Lessing can be added to Harker's list of writers for whom the Controversy was a formative moment. She also helps us to join the dots between this debate and the anti-Communist fiction that she went on to write. 
The orthodox Communist line on the Controversy was expounded and defended in the main intellectual organ of the British Party, the Modern Quarterly, edited by John Lewis. Lessing read The Modern Quarterly's reporting of the Controversy, which led her to question her status as a Communist writer. In a letter to Smithie she acknowledged that there was space for a politically committed 'literature which is designed to be propaganda, to explain a strike, exhort to action, analyse an epoch, for instance'. However, she went on,

[t]he present position in the U.S.S.R. [...] is bound to kill the only art worth having - that is, if the controversy in the Modern Quarterly reflects the position accurately. [...] [T]he writers of the articles explaining why it is right that Zoshenko [sic.] should be persecuted show a most narrow frame of mind which fills me with horror. I remember one of the counts against Zoshenko [sic.] was that he chose to write a book, or essay, I forget which, describing certain experiences of his youth. A man who chooses to write about a perfume he smelt fifty years ago rather than the erection of a new power station shows a retrograde state of mind - really Smithie! ${ }^{16}$

From her reference to 'perfume', one can surmise that Lessing must have been thinking of the following passage. It comes from a review of Zoschenko's Before Sunrise, which originally appeared in the Bolshevik (No. 2, January 1944), and was excerpted and translated for inclusion in The Modern Quarterly's coverage of the Soviet Literary Controversy:

Zoschenko's stories are based upon a petty bourgeois conception of the world; he paints an extraordinarily distorted picture of the life of our people. Entirely preoccupied with his own emotions, he forgets man lives in society. "I'm wretched and I don't know why," he 
begins and, to find solace, turns back to his past life to recall "those things which had made the deepest and most vivid impressions," emotional thrills, even smells! ${ }^{17}$

Lessing's encounter with these arguments, described in her letters, hints at a wider clash between her aesthetic and political commitments. In the private context of her letters, she was willing to advance robust claims for the autonomy of art. She told Smithie that

I think communists should understand that works of art are so precious ... that if an artist sits down in the middle of a revolution to write a witty essay on the folly of revolutions, for the sheer joy of paradox, he should be encouraged to do so.

To underline her point, Lessing even wrote Smithy a humorous poem that adopted the themes and tone that Zhdanov's strictures on socialist realism seemed to approve: 'I cant believe in a kind of urban hey nonny nonny, Put on your overalls, start up the motor, I'll give you sixpence, If you beat the quota. Put up the banners and take up the spanners... ad lib. ${ }^{18}$ This irreverent parody suggests that a literary art which adheres unthinkingly to Communist doctrine will end up both arid and unintentionally funny.

The socialist realism advocated by Zhandov and the Modern Quarterly was hostile to the modernism of Joyce, Proust, and Woolf - a hostility that goes back at least as far as Karl Radek's speech to the Soviet Writers Congress in $1934 .{ }^{19}$ In his Modern Quarterly editorial, John Lewis condemns 'that inward-turning, utterly corrupt and anti-social literary tendency which, since Joyce and Proust, has been characteristic of our dying culture. ${ }^{20}$ Lessing must have bridled to read the official organ of the Party condemning the writers she loved. She had written to Coll MacDonald in May 1945: 'Have been re-reading Proust with reverence. I shall never let anyone say a word against him in my presence. He is wonderful. ${ }^{21}$ In the same 
letter she describes a domestic conflict about Virginia Woolf that becomes a sort of cultural purge in a teacup:

I lent poor Virginia to Dorothy Zelter, who professes a love of Art, and when it was returned she said "such a sweet book, Tigger. But it has no beginning and no end." What I cry, outraged. Yes, it just stops in the middle. Whereupon I hurl To the Lighthouse across the room and flounce into bed. Then G[ottfried], annoyed says, don't be so intolerant. Do you really think that one should assess people's intelligence by whether they say what you consider to be true about Virginia Woolf? Whereat I am humbled. Do you think, I say meekly, that Lenin would have liked Virginia Woolf? No, says G firmly, therefore the conversation is closed irrev[oc]ably. But G says Lenin had a very fine taste in literature. Nonsense, I say. Every biography of him stresses the few books he read so admiringly that obviously they had to make much capital out of little. Which is true. Like Stalin laughing at a Congress. Three asterisks. And a footnote. ${ }^{22}$

Gottfried has assimilated the Communist Party's scepticism towards modernist art, and Lessing's letter suggests an emerging awareness that Lenin and Virginia Woolf are coming to represent two implacably opposed world views. Dorothy Zelter's reading of To the Lighthouse would seem to place it alongside Zoshenko and Akhmatova as an expression of bourgeois modernism — valuing fleeting impressions over narrative structure ('no beginning and no end'). As Harker shows, the Soviet Literary Controversy can be read as an important moment in the emergence of a Cold War cultural politics in which '[m] odernist works ... would function ... as aesthetic manifestations of an unfettered, exuberant individualism[,] in contrast to the collectivism so unconvincingly projected by Socialist Realism's repertoire of metallic clichés'. ${ }^{23}$ When Lessing's letter was written, in 1945, the cultural edifice of 
'modernism' was not yet so 'ideologically resonant' as it would become in the high Cold War. Yet she clearly felt that a false binary was opening up between a bourgeois modernism that was narcissistically fixated on interiority, and a kitsch, falsely optimistic Socialist Realism that imposed deadening constraints on the writer's imagination. For now (writing to Smithie in 1947) she decided that we must 'set our teeth and bear the nonsense that communists talk about art—it is comparatively unimportant' ${ }^{24}$

As Lessing established her literary career in London in the 1950s, she developed a perspective on these questions which sought to overcome the polarising opposition between bourgeois modernism and socialist realism. Most strikingly of all, when she travelled to the Soviet Union in 1952 alongside Naomi Mitchison, Arnold Wesker and others, she met Zoschenko himself - famously marginalised in the Zhdanov purge. Lessing clearly regretted her behavior and referred to 'the fellow-travellers of that time' as 'naive and stupid and ignorant' in a letter to Naomi Mitchison in 1985:

[T] hat trip [was] probably the most shameful experience of my life. Not least because for Zoschenko it was probably the last straw, being summoned to appear before Westerners at a time when contact with Westereners could and often did mean instant death. We bundled about, quacking and braying, like a parcel of spoiled children, among people only just surviving under one of the most brutal and arbitrary tyrants the world has seen. When I think of it all I want to die with shame. ${ }^{25}$

Lessing's memory of 'quacking and braying' suggests a totally unironic and automatic form of speech that could stick to the script without irony, and without putting metallic clichés in the safe confines of inverted commas. It is striking to observe, however, how Lessing's sympathy for Zoschenko's plight predated her meeting him in 1952, in the very different 
context of an attempt to normalise cultural-diplomatic relations between Britain and the USSR.

\section{$\underline{\text { The Small Personal Voice }}$}

When she arrived in London, Lessing continued the debate over the political functions of literature with a new set of interlocutors inside the Communist Party of Great Britain (CPGB). One of these was Jack Lindsay, the Australian-born novelist, poet and polymath, and a fellow member of the CPGB's writers' group. Lindsay was very far from inflexibly doctrinaire, but unlike Lessing, E.P. Thompson and the other key figures of the New Left he did not leave the Party in 1956. Lessing described him in 1995 as 'a hard-liner in a way I never was' - surely an exaggeration when it comes to Lindsay - and 'one of the many casualties of communist literary theory' ${ }^{26}$ But even during the years when she was a Party member, Lindsay had already begun to play the role of a 'hard-liner' in Lessing's mental picture of the group. In 1954, Lindsay's passion for the cultural programme of the Communist Party had made him the butt of Lessing's 'favourite joke':

Jack Lindsay, having just returned from Roumania and of course being full of revolutionary enthusiasm, promptly sat down and sent us all a peremptory circular. Which read something like this:

What are you writing?

Why?

Is it any good?

Does it further, etc. 
What have you done in the last year to preserve and further the Cultural Heritage of Britain?

I malign him a little, but not much. ${ }^{27}$

Lindsay recalled some of his debates with Lessing in an unpublished memoir written in the 1970s. In one anecdote from their time together in the Party, Lindsay tells how he and Lessing had been asked to speak to a regional meeting of Party literature secretaries, on the theme of 'the writer's role'. In the discussion, Lessing pointed to a problem of scale: that the realist writer was confronted with a society that had become too large and complex to be encompassed in one omniscient perspective, a feat achieved by the great nineteenth-century realists under different conditions. Lindsay writes:

Doris claimed that modern society was too huge and complicated for the writer to deal with more than the small section that he knew intimately. I replied that Balzac, Dickens, Zola had had a much less extended and entangled society, but it had already become much more than any one could compass in his personal experience; they had to fill out their direct knowledge with imaginative insights and sympathies of all sorts. While the writer of today must beware of schematisms and stereotypes of abstract social constructions, in his work, he too must use his imagination, which, supplemented with a genuine Marxist comprehension, would enable him to achieve the broad view of a Balzac as well as the intimate details, if only he had the genius. Anyway it was up to him to test himself out to the limit, not to hedge him in with a timid acceptance of preconceived limits. $^{28}$ 
Lindsay's framing of the debate owes something to the work of Georg Lukács, whom he admired, and had met in Wroclaw in $1948 .{ }^{29}$ In his defence of the idea that the realist novel could (and should) represent the totality of social relations, Lindsay goes rather further than Lukács did. ${ }^{30}$ Even a lyric poem or a song could perform this role for Lukács: the realist work could get at wider social reality through an intensive depiction of one element of society. These questions are also at the heart of Lessing's essay 'The Small Personal Voice' (1957), her most programmatic public statement on the political function of art.

‘The Small Personal Voice' was first published in Declaration, a collection of literary manifestoes by the Angry Young Men generation, edited by Tom Maschler. The argument she sets out there resonates powerfully with her earlier encounters with Soviet orthodoxy on literary questions. The first thing to note is that 'A Small Personal Voice' in some respects echoes the Soviet critique of the 'more decadent productions of Western bourgeois culture'. ${ }^{31}$ Lessing here writes of 'despairing statements of emotional anarchy'. Rather than indicting her beloved Proust and Woolf, Lessing lays this charge at the door of 'writers like Camus, Sartre, Genet, Beckett' (also criticised by Lukács in 'The Ideology of Modernism' that same year). ${ }^{32}$ Offering an alternative to 'the pleasurable luxury of despair, the acceptance of disgust', 'The Small Personal Voice' makes a programmatic case for realism: 'the highest point of literature was the novel of the nineteenth century, the work of Tolstoy, Stendhal, Dostoevsky, Balzac, Turgenev, Chekov; the work of the great realists' (p.8), Lessing writes. Moreover, 'literature should be committed' (p.10). However, in ironic tones recalling her earlier letters on this subject—Lessing also distances herself from the idea that "novels should be simple tracts about factories or strikes or economic injustice' (p.7). Her essay aims to steer a middle way between bourgeois individualism and Communist collectivism: 
One sees man as the isolated individual unable to communicate, helpless and solitary; the other as collective man with a collective conscience. Somewhere between these two, I believe, is a resting point, a place of decision, hard to reach and precariously balanced. (p.15)

Lessing's early engagement with Soviet approaches to literature forced on her mind an opposition between the Socialist Realism promoted by Zhdanov on the one hand and a radically individualistic, polylogic and polysemic modernism on the other. She refused to take one side in this Cold War politicisation of literary taste. Her argument in favour of a committed realism is thus combined with the notion that the novel is an intrinsically individualistic form: 'The novelist talks, as an individual to individuals, in a small personal voice.' Moreover, this was one reason why the novel was ripe for a revival: 'In an age of committee art, public art, people may begin to feel again the need for a small personal voice.' (p.25). The novel form itself, for Lessing, implies a route out of the enforced collectivity that she encountered in the Party. Nevertheless, that small personal voice was also a strident political actor, an 'architect of the soul' (p.11) (Lessing uses Stalin's phrase) conceived in opposition to the 'isolated individual unable to communicate, helpless and solitary' (p.15), which she associated with Beckett, Camus and Sartre.

One problem faced by those who sought to write in the tradition of Balzac and Tolstoy was the crisis of scale that Lessing had debated with Jack Lindsay, and the smallness of her 'small personal voice' was part of her answer to that-working along the lines of Lukács's ‘intensive totality'. As well as grappling with unmanageably large totalities, Lessing argued that contemporary realists also faced a crisis of vocabulary. Marina MacKay argues that that writers who embraced realism in the mid-century were reacting against 'perniciously antireferential forms of language' which they associated with modernism, but also with 
totalitarian politics. For MacKay, the return to realism in mid-century writing is 'not ... simply a default position for second-tier novelists', but an 'effort to repair ... a war-broken relationship between words and things' ${ }^{33}$ Lessing can be seen as part of this wider trend. Her diagnosis of the linguistic problems facing contemporary realism focussed on the perceived loss of an agreed moral vocabulary, on which Balzac and Tolstoy relied. The moral certainties which seemed to her to animate the great realist novels were part of a nineteenthcentury cast of mind whose subsequent decline was a particularly acute problem for writers because those certainties related to a novelistic language that had become unusable:

It would be hard, now, for a writer to use Balzacian phrases like 'sublime virtue' or 'monster of wickedness' without self-consciousness. Words, it seems, can no longer be used simply and naturally. All the great words like love, hate; life, death; loyalty, treachery; contain their opposite meanings and half a dozen shades of dubious implication. Words have become so inadequate to express the richness of our experience that the simplest sentence overheard on a bus reverberates like words shouted against a cliff. $^{34}$

For this reason, it is difficult to frame Lessing's early work as a 'return' to realism after modernism: such terms may have been used 'simply and naturally' by Balzac, but there is no going back. One either uses the old language with extreme caution, and a troubling awareness of its demonic, excessive resonance, or perhaps, one reaches for a new language. In Lessing's case, the origins of this crisis of novelistic language ought to be seen in relation to her earlier experiences in the Communist Party. Marxism supplied a means of critiquing 'bourgeois' conceptions of the beautiful and the good (and so forth), casting doubt on this vocabulary which was an indispensable tool for the nineteenth-century realist. Writing to John 
Whitehorn, she discusses the Communist challenge to a vocabulary of 'bourgeois' aesthetics and morality. She alludes to an argument with Smithie in which he had objected to the word 'artistic', on some political grounds or other-the details are not recorded but it is possible to guess the line of argument. Here is what Lessing writes in response: (it will be useful to know that the 'Mr. Huggins' she refers to is Godfrey Huggins, the prime minister of Southern Rhodesia from 1933-53):

To th return to the word artistic. I think that to all of us who have spent most of our lives battling to be individuals in an unsympathetic world, (I speak for myself) words used by people like Mr. Huggins like love, beauty, artistic and such like are soaked in philistinism and general hideousness.

In other words, we have acquired an elaborate system of self-defence, and in order not to be pained by what Mr Huggins would mean by love, beauty, artistic etc. we cease to even to use such words. It is, in fact, muddied thinking. ${ }^{35}$

The words Lessing instinctively wants to use, the ones she was accustomed to encounter in Balzac, now ring hollow in the mouths of the racist colonial authorities, tainted by the hypocrisy of the regime. Marxism furnished her with a suspicious hermeneutic capable of exposing that hypocrisy, labelling it 'bourgeois morality' or 'bourgeois aestheticism'. It set out to expose the supposedly timeless verities of moral goodness and beauty as historically contingent products of the capitalist mode of production, and - worse - as elements of an ideological superstructure that helped to secure the lasting hegemony of the ruling class. The 'muddied thinking' for Lessing_exemplified in Smithie's squeamishness about the word 'artistic' - inheres in the use of Marxism as a purely destructive mode of critique that deprived Communists of a meaningful vocabulary with which to discuss love, beauty, art, 
and morality, and ceded a monopoly on that language to the deplorable Hugginses of the world.

\section{Language and Dogma}

Marxism provided Lessing with a critical apparatus for revealing the hypocrisy of bourgeois pieties about art and morality, but she was quick to notice that it also came with its own distinctive vocabulary. That specifically Communist lexicon - the language of dialectical materialism and of the Party_-became one of Lessing's major preoccupations as a writer. This language seemed to have sprung up within the Party to replace 'great words like love, hate; life, death; loyalty, treachery'. Much later, in her autobiography, Lessing reflected on this:

The most interesting thing to me now is the language we used. For years we have been laughing at phrases like capitalist hyenas, social democratic treachery, running dogs of fascism, lackeys of the ruling class, and so on. They would fill a dictionary. Laughwhen this language was the weft and woof of indictments that sent millions of people to their deaths... Introduced to this vocabulary of contempt our first impulse was to laugh nervously... We were playing a role. The play had been written by 'History' - the French Revolution, where the language was first used, and the Russian Revolution — and we were the puppets who mouthed the lines. We could not use it without laughing... We put the phrases between inverted commas, or exchanged glances while demurely mouthing them. ${ }^{36}$ 
Lessing presents Communism as a set of ritualised linguistic clichés that have the power to shape behavior. Though it was written from the anti-Communist position Lessing had taken by the 1990s, her autobiography suggests a useful framework for thinking about Communist language in her earlier work. Lessing suggests that Communist language operated as a determining set of conditions: certain countries, movements, and groups 'have been taken over by language' (p.276), and that in turn shaped behaviour. Her group found themselves 'playing a role', acting out a scenario that was entirely pre-scripted. Yet Lessing also points out that this 'play' is 'written by 'History', Lessing describes a static language that is fixed in place by dynamic historical events, raising interesting questions about the temporality of Communism that resonate in her novels.

By drawing so much attention to the ways Communists speak and write, Lessing suggests that Third International Communism - though it was forged in a moment of dynamic historical rupture - is experienced cyclically, as a repeated set of linguistic and attitudinal clichés. This is made very explicit at that end of Landlocked (the fourth instalment of the Children of Violence sequence) when an increasingly jaded Martha and some of the other veterans of her group join a meeting of younger socialists. Martha is 'strongly transported back to ... that other group' and surveys the room with a knowing sense that a pattern is being repeated, with all the outcomes known in advance: 'if history was repeating itself — and why not? If the dramatis personae were the same, presumably the plot was also. ${ }^{37}$ She looks forward in time to the disillusionment of those around her, who will inevitably end up telling themselves 'if only' this or that had been done differently, the group might have succeeded. '[I]t always happens like this; that is the point', Martha reflects, inwardly, 'that 'if only' shows you never understood the first thing about what was going on' (p.342). Following a fractious discussion about the rise of Communism in China, the meeting's chair says: 'I'm going to put it to you: in fact, everyone's saying the same thing'. This creates a false 
consensus that allows those present to believe that they are speaking in unison:

They all looked at each other again: not really friendly, this look, for they didn't want to be like each other, to be similar, although the violence of their discussion had, in fact, caused an underlying good feeling. But they saw it: they had, in fact, been saying, though of course in very different ways, the same thing. They laughed, all together. The laugh made them one. (p.345)

The repetition of 'in fact' is taken up from the chair's statement and becomes part of the group's collective internal utterance. Lessing depicts this through the ingenious use of collective free indirect discourse. Martha is now at a sufficient distance from her own period of immersion in her group to see the dangers, as well as the seductive appeal, of speaking, or laughing, in unison. (The laughter itself is significant_-implying that part of the 'good feeling' in the group comes from a shared ironic distance from the agreed line supposedly held in common.) Where these young socialists are able to deceive themselves that they can navigate with ease between the individual and the collective, retaining their individuality even as they speak and laugh with one voice, Martha sees them following an entirely predictable pattern, destined to repeat itself: 'It is the self-flattering, comforting, warming laugh heard - but how many times in how many settings had Martha heard it! And how many times and in what circumstances would she hear it again?' (p.345).

This scene from Landlocked is set in 1949, but written in 1965, after Lessing had more experiences in the British far left to draw on. Smithie wrote to Lessing to ask her about this young group. She replied: 
The group at the end came out of my experiencing the New Left crowd here in 1958. It was all deja vu. Quite uncanny. I sat at one or two of those meetings with my scalp crawling, so much did people, speeches, attitudes repeat themselves. ${ }^{38}$

Lessing nods back to her and Smithie's shared experience in the Left Club in Salisbury, suggesting that these groups - far from offering a dynamic revolutionary break with historical precedent - repeat patterns of speech and attitude to the extent that they exist in a state of stasis. Communist language is a repetitive, cyclical structure that seems to have emerged from, and now co-exists with, forms of dynamic historical change (like revolutions). Writing about the French and American revolutions, Hannah Arendt refers to what she calls the 'condensation of happenings into concepts'. ${ }^{39}$ This arresting phrase describes well the process by which an absolutely novel event ends up producing a script and a set of fixed concepts that are repeated cyclically by 'puppets who mouthed the lines' (as Lessing put it). ${ }^{40}$ Condensation is an apt metaphor for the way dynamic happenings are transformed into longterm structures in Lessing's work.

Reinhart Koselleck proposed a related metaphor of sedimentation in his essay 'Sediments of Time', as a way of getting around the 'linear-cyclical dichotomy', which he sees as a pervasive way of thinking about historical time. He argues persuasively for a more flexible understanding of historical time that would take for granted that 'every historical sequence contains linear as well as recurrent elements. ${ }^{41}$ Alongside singular events that produce change in an apparently linear fashion, Koselleck writes, there exist 'structures of repetition that are not exhausted in singularity'. Language is a case in point. A single utterance can produce a new meaning, but only in the context of a 'preexisting linguistic inventory', that 'changes only very slowly, even when something entirely new is put into words'. ${ }^{42}$ The language of Communism emerged out of the American, French and Russian Revolutions, but 
once established it formed a relatively static element of the historical landscape. Languages require a pattern of repetition to make sense, but they are not entirely cyclical, changing only slowly, in the medium term. Koselleck thus sets out to comprehend 'different speeds of change and transformation without falling prey to the false alternative between linear or cyclical temporal processes' ${ }^{43}$ This exposes some of the limitations of the periodising frames through which we tend to understand literary history, and is helpful in the present context, as the specific 'linguistic inventory' of Communist language evidently emerged from rapidly changing events, but also fixed itself over several generations as part of a 'structure of repetition'. Metaphors of condensation or sedimentation seem to me suggestive ways of capturing this process.

Questions of historical temporality are important to the ways Lessing represents Communist language in her fiction. In A Ripple from the Storm, the members of Martha's Communist group use the pat phrases of revolutionary socialism, while also criticising the unthinking use of such phrases. Anton plays the role of the Marxist theoretician, pulling the others into line when they deviate from his understanding of Marxism-Leninsim. In one of his frequent criticisms of the activities of the group, he says:

'a real communist never takes an action which does not flow from a comprehensive understanding of the economic situation in a given situation and the relation of the class forces. We have merely rushed into activity spurred on by revolutionary or so-called revolutionary phrases.' 44

Despite his professed contempt for 'so-called revolutionary phrases', Anton is not himself immune from using clichéd formulations. His oft-repeated injunction to 'analyse the situation' has become his own mantra, and is treated with a certain irony by the group: 
'The sort of thing that happened tonight is a direct result of not seriously analysing the situation...'

Here they smiled: the phrase, analysing the situation, was particularly Anton's.

'Yes, comrades. Analysing the situation.' (p.28)

Anton presents his position as the product of a dispassionate and rational application of Marxist logic. His repeated refrain is to resist the call for immediate action, whether directly political and revolutionary, or simply philanthropic attempts to help some of the people currently being chewed up by the colonial regime (help that many members of this wellmeaning group are desperate to give). To 'analyse the situation' is not a plea that belongs to Anton 'particularly' —it is itself a kind of Communist cliché. From Brecht's Die Maßnahme (1930) to Koestler's Darkness at Noon (1940), the literature of Communism is littered with examples of young, enthusiastic comrades who are liquidated for acting too quickly, motivated by passionate sympathy for the downtrodden, rather than obeying the cool and dispassionate analysis that says that the time is not yet ripe. In Die Maßnahme, for example, the Young Comrade is advised by four agitators to 'recall comrade Lenin's classic advice' and wait for the correct time to take political action. He insists that 'man, real live man, is crying out, and his misery rips through the limitations of their teachings. This is why I shall launch the operation instantly and at once. ${ }^{45}$ The Young Comrade is killed by the four agitators and thrown into a lime pit, his empathy an obstacle to the revolution. Who is the puppet, mouthing the predictable and clichéd tropes - the Young Comrade or the four agitators? In A Ripple from the Storm, Anton says that ill-advised revolutionary passion is stoked up by the unthinking repetition of set dogmas: the rest of their group, in their heartfelt efforts to help the black population, are like the Young Comrade, foolishly susceptible to 'so- 
called revolutionary phrases'. Yet Lessing's text hints that his brand of cool reasoning is just as predictably formulaic in its modes of speech and thought.

Anton's professed aversion to 'revolutionary phrases' is seemingly undercut when he enjoins the other members of the group to learn a Communist mantra by rote, as he chastises them:

'[Anton's] face stiffened, and, looking before him at the dirty wall, he said in a soft exalted voice: 'Yes. It is hard to become a real communist, a communist in every fibre. It is hard, comrades. I remember when I first became a communist, I was given some words to learn by heart, and told to repeat them whenever I became filled with doubts or despondency.' He raised his voice and quoted: 'Man's dearest possession is life; and since it is given to him to live but once, he must so live as to feel no torturing regrets for years without purpose; so live as not to be seared with the shame of a cowardly and trivial past; so live that, dying, he can say: All my life and all my strength was given to the finest cause in the world - the liberation of mankind.' His face was strained with exultation. He turned and went out, without speaking.

'But I know that,' said Marjorie, aggrieved. 'I've got it written out and pinned over my bed.'

'So do I,' said Jasmine.

'We all know it by heart,' said Martha. They all felt misunderstood by Anton, and held to be smaller and less heroic than they were. 'It was the first thing of Lenin's I ever read,' she added. ${ }^{46}$

Even an individual presented as dogmatically Communist (such as Anton) can be expected to experience 'doubts or despondency'-Anton asserts that these can be overcome by a return to 
certain agreed scripts. The passage Anton quotes here is a fascinating example — not, in fact, by Lenin at all (despite Martha's confident claim), but a from Nikolai Ostrovsky's classic of socialist realism, How the Steel was Tempered (pt.1 1932, pt.2 1934). This passage was and still is much quoted, and often misattributed - it seems to have circulated quite widely in a form detached from its original context in Ostrovsky's novel. The passage is variously attributed to Lenin, Kemal Faruki, and Jawarharlal Nehru, as well as Ostrovsky. Some report that the passage was printed on a card which they carried with them at all times. ${ }^{47}$ The translation that Lessing quotes here is not from Prokofieva's English translation (first published in 1952 by Progress Publishers, Moscow). No other complete translation of the novel into appears in the British Library catalogue. This exact translation of the passage does appear in Nehru's The Discovery of India (1946), where it is wrongly attributed to Lenin. ${ }^{48}$ Perhaps this extract alone - the one Anton quotes - was independently translated from the Russian, to circulate in Communist and anti-colonial circles, where both Lessing and Nehru encountered it. ${ }^{49}$ Or perhaps Lessing first encountered the passage in Nehru's book in 1946, inserting it anachronistically into A Ripple from the Storm, which is set during the war. The fate of this passage helps to illustrate the way in which certain agreed scripts tended to circulate within (and beyond) the Communist International, over several generations, to the extent that the original context of the utterance-not just the fictional character who spoke the words in the novel, but the novel's author too-fall away. Whether Lessing misattributed this passage to Lenin, or whether she ironically imputed the mistake to Martha, Lessing is interested in the way such utterances detach themselves from their original contexts and become part of the collective utterance of Communists in general.

The language of revolution became crystallised in the early years of the Soviet state, as part of the condensation of happenings into concepts. Though it is sometimes portrayed as a language of enthusiasm and dynamic radicalism, Lessing seems equally interested in the 
Marxist language of scientific detachment that urges not action but contemplation and 'analysis'. Brian Cummings has recently remarked that one function of the language of the Christian liturgy is 'to speak across or even outside of time', and that liturgical language is 'peculiar in that it is poised in a continuously present tense' ${ }^{50}$ Lessing is charting the consolidation of a form of Communist liturgy which also inhabits this permanent present tense. For Walter Ong, stock Communist phrases like 'enemy of the people', 'capitalist warmongers' or 'The Glorious Revolution of October 26', were to be understood as a form of 'obligatory stabilization' - as if such epithetic formulae were designed (however consciously) to arrest the rapid pace of historical change by establishing a repeatable liturgy to rival that found in the Book of Common Prayer. 'Once a formulary expression has crystallized it had better be kept intact', Ong concluded. ${ }^{51}$ It is in keeping with the stabilising force of such language that it should often — like Anton — counsel a stoical attitude: 'analyse the situation', rather than rushing to take action. Like the Lord's Prayer, the passage from Ostrovskymemorised and repeated as an expression of faith—-holds together a community across generations as they utter the same words. Lessing herself underlines the temporal implications of this in A Ripple from the Storm:

during the last few decades when people in the West have suddenly become communists, they have always been contemporaries of Lenin. They felt themselves to be in a vast barbaric country (though not their own) sunk in the sloth of centuries, members of a small band of men and women with rifles in their hands, prepared to die for the future. (p.45). 
The mentality and the language of Communism are thus presented by Lessing as persistent 'structures of repetition' and are experienced synchronically in the kind of permanent present tense that Cummings associates with liturgical language.

This parallel with the Christian liturgy suggests a way of understanding Communist language primarily in terms of spoken discourse, as a public, ritual performance - in line with Ong's argument that it formed part of a 'residual orality'. This makes Lessing's letters to the Cambridge RAF a particularly interesting place to encounter such language, and the discussion of it. Taken as a medium, letters are private, one-to-one communications that might be thought of as intrinsically resistant to groupthink. As we have already seen, even when she identified strongly as a Communist, Lessing expressed in her letters a considerable independence from the Party line, and mocked expressions of Communist commitment that she considered to be too doctrinaire. Looking at the letters to John, Coll, and Smithie together, one is observing a single individual thinking about essentially the same ideas, situations, and events, but writing in three different directions to her different interlocutors. The correspondence reveals a fascinating interplay between the group dynamic and the individual relationships that go to make it up.

Of her three interlocutors in the Cambridge RAF, Smithie was the most committed Communist (Ted, his fictional counterpart in The Golden Notebook, is described as 'the most original ... from a large working-class family ... the only genuine socialist of the three, ${ }^{52}$ ). Lessing's letters to Smithie were certainly shaped by the shared understanding that she was addressing a 'genuine socialist', but in no sense did they avoid the difficult topics that confronted Communists as they learned about events in the U.S.S.R.. Among the many books that Smithie sent to Lessing were Arthur Koestler's The Yogi and the Commissar (1945) and Victor Kravchenko's I Chose Freedom (1946) - two notorious books by ex-Communists that became influential in mobilising anti-Communist sentiment in the Cold War period. Both 
books triggered crises of commitment in Lessing, and the varying ways in which these crises were communicated (or not) to her correspondents is revealing.

Lessing's palpable distress after a sleepless night reading Koestler was communicated first to John — with whom she was then having a passionate affair-on 15th August 1945. In this letter she writes that she has been 'very shattered by' Koestler's book, and that she is 'engaged in mental crisis'. She confesses 'complete mental bewilderment', coming to the conclusion, based on Koestler's description of the Soviet Union, that 'the materialist conception of history in the Marxist sense ... is faulty and no guide to what is going on. ${ }^{53}$ However, she knows that John (not a 'genuine socialist') will not suffer the same pain: 'I suppose you get sick of our mental crises, but darling John, having never fallen in love with communism how can you know what it feels like to have your beloved besmirched? You cant.' After setting out some of the substance of Koestler's critique, she writes: 'Sorry for all the above. I envy your detachment which must save you much agonising'. ${ }^{54}$ She writes with some irony about the correct 'dialectical' response to Koestler, and notes that 'what I like about dialectics is not the dubious tactics it is used to justify, but that it explains what I feel about life'. ${ }^{55}$ In her next letter to John, two weeks later, she says she is 'no longer deeply depressed, merely at a loss' ${ }^{56}$ As well as the intimacy of their love affair, John's 'detachment' from the Party seems to be one of the reasons she can be so open about her doubts - though perhaps in her apology there is also the implication that, as an outsider, he is spared the pain that Lessing was in, and unlikely to understand it fully.

Lessing did not write to her fellow Communist Smithie (the one who had actually sent her Koestler's book) until $6^{\text {th }}$ September. He had clearly also been suffering after reading The Yogi and the Commissar, as Lessing writes: 'I can quite sympathise with you-it made me miserable and I had nightmares for days. ${ }^{57}$ Compared with the letter to John, her letter to Smithie is different in tone, attempting to absorb Koestler's arguments dialectically and re- 
establish commitment: 'You should try and get the broad development of things as a whole', she tells him. 'When its a question of us surviving at all (human beings) why should one get excited if Molotov talks nonsense about culture? He does. He will. So he should, if its o.k. in the long run.' ${ }^{58}$ The Party is 'only a necessary and imperfect instrument for social change', but its imperfections must be accepted since it it the only progressive force available. She writes: 'We should recognise that communists are dogmatic, often stupid, and narrow. But if they werent they would spend their time sitting around in corners speculating about the nature of reality, instead of doing their work without which everything would go back. ${ }^{59}$ This letter is hardly the rallying cry Lessing seems to want it to be, but in its attempts to swallow Koestler's uncomfortable arguments and rally Smithie to the Communist cause, there is a palpable contrast with the letters to John.

There is an interesting shift in the way Lessing talks about Communism with the two men. Two years after the discussions about Koestler, another crisis arises after Lessing and Smithie read Kravchenko's I Chose Freedom. This time it is Smithie who receives the soulsearching letter. Lessing starts by reeling off a list of problems with Stalin's Soviet Union: collectivisation, the purges, nationalism, the leader cult, a 'childish attitude towards the arts' and 'worship of a Victorian standard of morality'. She goes on:

For every one of these things, being a fairly thoroughly trained marxist (I havnt lived with $G$ [ottfried] for four years for nothing) I could produce an elaborate justification. And still can, provided ... that the communist party of the Soviet Union ... still stands for what it stood in Lenin's time.

Now, if Kravchenko is correct, nothing remains but lipservice towards this ideal and there is ... a reign of terror [in the U.S.S.R.] that is much worse than anything Hitler 
thought of. Well, I know all the answers to this, Smithie, so please dont insult me by sitting down to write a pep talk about bourgeois something or other. ${ }^{60}$

The last sentence here anticipates and preemptively deflects exactly the kind of 'pep talk' she had written to Smithie about Koestler. There is, Lessing suggests, a sort of pre-scripted dialectical response to Kravchenko which is entirely predictable and embedded in the mentality of party members-Lessing knows the dialectical steps she would need to articulate an 'elaborate justification' of the things Kravchenko reports, and there is no need for Smithie to rehearse them. The parenthesis in the first sentence quoted suggests that Gottfried plays an important role in teaching Lessing the lexicon and the argumentative style of Communism, just as Anton (his fictional equivalent in the Children of Violence series) reminds the group to 'analyse the situation' and to learn and repeat the passage from Ostrovsky. There is always a third voice in this correspondence: a set of pre-scripted, dialectical responses that both correspondents dance around knowingly. In the debate about Kravchenko, this time it is John who cannot be let in on Lessing's wavering commitment (perhaps their love affair was waning in its intensity, and she became less willing to share her doubts with him, or perhaps Lessing felt the mounting pressures of the Cold War). She writes to Smithy: 'If you are at this moment labouring to make of John a communist, then better not breathe a word' ${ }^{61}$ The crisis she confronts can be shared with another Communist, but on the basis of an intimate pact that they will present a united front to others. She never mentions Kravchenko to John, and in subsequent letters to him she employs the familiar logic: 'In spite of my hearty loathing of most of Russia's actions at the moment, I recognise their necessity. ${ }^{92}$ Lessing's letters from this period thus reveal a complex interplay between the corporate identity of the group, the one-to-one relationships that the letter as a medium presupposes, and a set of pre-scripted 
'dialectical' arguments that all the correspondents are aware of, and treat with varying degrees of scepticism and irony.

\section{Linguistic Alienation}

Lessing's work after leaving the Party in 1956 frequently explores the effect on individuals of becoming alienated from a shared political language. In Landlocked (1965), the fourth instalment of the Children of Violence sequence, Lessing compares Martha's life in the colony with living in a 'house with half a dozen rooms, each room full of people (they being unable to leave the rooms they were in to visit the others, unable even to understand them, since they did not know the languages spoken in the other rooms). ${ }^{93}$ There is no shared language that would bring the balkanised linguistic communities of the colony together. The all-embracing Balzacian vocabulary of 'love, hate; life, death; loyalty, treachery' has been cast into doubt. Martha now sees the Marxist language used by Anton and the others as one language among many, not as the master discourse capable of unlocking them all. She feels simply trapped (landlocked, even) in a series of isolated conversations. The novel sees her cycling 'like a maniac' between the mutually incomprehensible discursive worlds of the colony, while she scolds herself for waiting for a man who (she wistfully allows herself to believe) could 'unify her elements'. ${ }^{64}$ Martha's romantic notion that a man will resolve all her problems is treated satirically in Landlocked, but it is also the case that politics has receded as a possible answer to the questions posed by the novel.

The Golden Notebook portrays a similar feeling of alienation from a common language, linking this very directly to the question I have raised in relation to Lessing's 1940s letters: how does a Communist speak to those within the Party as compared with those outside it? Anna writes in her red notebook: 
$19^{\text {th }}$ August 1951

Had lunch with John, the first time since I joined the Party. Began talking as I do with my ex-Party friends, frank acknowledgement of what is going on in the Soviet Union. John went into automatic defence of the Soviet Union, very irritating. Yet this evening had dinner with Joyce, New Statesman circles, and she started to attack Soviet Union. Instantly I found myself doing that automatic-defence-of-Soviet-Union act, which I can't stand when other people do it. She went on; I went on. For her, she was in the presence of a communist so she started on certain clichés. I returned them. ... Fascinating- the roles we play, the way we play parts. ${ }^{65}$

In her friendship with her fellow Communist John (not to be confused with John Whitehorn in the context of the present discussion!), Anna feels she ought to be able to set aside the 'automatic-defence-of-Soviet-Union act' — a script they both know well—and engage instead in some 'frank discussion'. John insults her by reaching for a familiar dialectical response, refusing to partake in the kind of intimate pact that existed between Lessing and Smithie, and in effect treating her as a non-Communist. Anna then nevertheless keeps up her end of the bargain, producing the required 'clichés' in her encounter with the liberal left of the 'New Statesman circles', and apparently almost losing control of her own speech as a purely 'automatic' discourse takes over. Elsewhere, when Anna is reflecting on her own reading of Koestler, she notes that 'there is no Party member I could say this to' whereas 'it's the sort of discussion I have with ex-Party people'. Such a refusal to conduct a 'frank' discussion of the problems of the Soviet Union again intrudes on Anna's personal relationships when she complains of her friend Molly that, when they discuss politics, 'I never know what person is going to reply - the dry, wise, ironical political woman or the Party fanatic who sounds, 
literally, quite maniacal.' At the same time, Anna acknowledges that if another acquaintance, Rex, were to make 'a crack about the Party', she would defend it, slipping into a dialectical pep talk. 'One becomes isolated,' Anna continues. 'That is why I shall leave the Party' ${ }^{66}$ Reflecting on the way in which Communist language and its argumentative styles affect individual relationships, The Golden Notebook turns explicitly to the letter form, which is ideally placed to investigate the relationship between individual, one-to-one, personal relationships, and the shared scripts of political commitment. Lessing uses letters to dramatise and analyse the discussions within Anna's party cell in response to events of 1956 (which led to Lessing's own departure from the Party). Anna describes to her friend Molly the response of three comrades, Tom, Len and Bob to the news of 'various plots' in Moscow:

'I suddenly got letters from all three of them - independently of course, they didn't know, any of them, the others had written. Very stern, they were. Any rumours to the effect that there was any dirty work in Moscow or ever had been or that Father Stalin had ever put a foot wrong were spread by enemies of the working class.'

Anna describes how she typed all these letters out in order to compare them: 'these letters were interchangeable. .... In phraseology, style, tone, they were identical. You couldn't possibly have said, this letter was written by Tom, that one by Len.' Then, after Khrushchev's so-called 'secret speech' at the twentieth party conference, Anna gets three more letters and notices the same effect:

'Then came the Congress and almost instantly I got three more letters. All hysterical, self-accusatory, full of guilt, self-abasement. ... They might have been written by the same person. Do you see?' 
'No. What are you trying to prove?'

'Well, surely the thought follows - what stereotype am I? What anonymous whole am I part of?'

'Does it? It doesn't for me.' Molly was saying: 'If you choose to make a nonentity of yourself, do, but don't stick that label on me., ${ }^{67}$

Though Molly is unimpressed by her experiment, Anna is interested in the way-even in letters - freethinking individuals can turn out to be unconsciously following a script. This is not simply about political position, but also about a way of writing: Anna emphasises that 'the style, the phrases, the way words were linked together' in all three letters were identical. Anna's question — 'what stereotype am I'—-serves to underline Lessing's refusal of a Cold War binary that would simply contrast Communism's enforced collective monologue (embodied also in socialist realism) with the multi-voiced individualism of bourgeois modernism. Anna's question would imply that modernism itself - at least its Cold War form-also offers stereotypical modes of expression. Such an analysis would lend weight to Fredric Jameson's classic argument that modernism degenerated into a 'host of distinct private styles and mannerisms'. ${ }^{68}$ The very variety of those styles and mannerisms makes a case for the pluralism of Western liberal culture, each style encapsulating a highly individualised way of seeing the world. But each style is also in itself a repeatable pattern, a static linguistic inventory.

This episode casts valuable light on the formal structure of The Golden Notebook. Instead of three people inadvertently writing identically as they reproduce the shared scripts of Communist commitment, in The Golden Notebook one individual, Anna Wulf, writes different things in four different directions in her red, green, blue and black notebooks. This gives the sense of a self whose parts cannot be made to speak in unison or with one voice. 
Like the colony in Landlocked, The Golden Notebook is a house with several rooms whose inhabitants do not 'know the languages spoken in the other rooms. ${ }^{69}$ Martha, like Anna, becomes isolated as she strives to mediate between these incompatible languages, a lone individual speaking in several mutually incompatible voices. When Anna does encounter people speaking in unison, using the shared scripts of Communist language, the effect is not to produce a community based on shared ideals, with this language as the common ground on which all can agree. On the contrary, as we have seen, these shared scripts are paradoxically isolating. In a conversation where all parties know or can guess what the 'line' is, the real meaning is to be found not in the words and arguments themselves, but in the decision of one or other of the group to activate an essentially automatic discourse. Communist language shares with liturgy the properties of a set form of words that the congregants know by heart. In Lessing's work, unlike liturgy, it rarely performs the rhetorical function of uniting all speakers around a shared set of beliefs. At best, there may be group-cohesion to be found through ironic eye-rolling at this predictable and automatic speech. Used in earnest, however, it is a barrier to intimacy; not the basis of an imagined community, but profoundly isolating instead.

\section{$\underline{\text { Conclusion }}$}

Lessing's early intellectual development has until now been understood largely through her later writings, largely because the archival record has until quite recently been inaccessible. The letters I have examined here add significant texture to Lessing's later explorations of Communist commitment, both fictional and autobiographical. They are not the letters of a writer under the intoxicating spell of a religious conversion. On the contrary, they show that Lessing's intellectual formation as a Communist was a training in skepticism, irony, and 
detachment. This was crucial to the way that she began to theorise the novel as a form uniquely capable of investigating 'the individual conscience in its relations with the collective' ${ }^{70}$ The Zhdanovite socialist realism that she debated in her letters to Smithie prescribed a shared novelistic language that was impersonal (forbidding too much emphasis on sensory impressions, childhood memories, intimate relationships) and kitsch in its false optimism. Lessing began to recognise this as a monologic form of collective speech that - far from embodying the dynamism of revolutionary change — operated as a static linguistic inventory, frozen in time, which moreover had the power to 'take over' in dangerous ways. Seeking an approach to the novel that could put this language in its place, in works like $A$ Ripple in the Storm, The Golden Notebook, and Landlocked, Lessing explored that language both from the inside and the outside, positioning it as one language among many in a polyglot society, which merely purported to be a kind of master discourse that could explain all the others. There was also no possible return to the novelistic vocabulary of Lessing's nineteenth-century novelistic heroes, Balzac and Tolstoy, which was grounded in moral certainties that had been exposed and destabilised as the twentieth century reckoned with colonialism. The female protagonists of the novels I have discussed are confronted with a number of mutually incompatible linguistic universes, and as they navigate between these, they are essentially alone. There is no available shared language: the 'dialectical' style of Party speech that aspires to the status of metalanguage but actively blocks real conversation. Lessing's take on the novel certainly involves a stress on the importance of individual experience, in the face of the enforced collectivity that she associates with socialist realism. But as I have argued, Lessing also sought to resist the Cold War polarisation of realism and modernism, and it would be reductive to understand her trajectory simply as that of a Cold War liberal embracing bourgeois individualism. In a sense her individualism runs deeper, 
because it refuses to be corralled into the collective project of Cold War Atlanticism—she

refuses to be what Arendt called a Communist turned upside down.

${ }^{1}$ Richard Crossman, 'Introduction' in Crossman (ed.), The God that Failed (New York, NY: Harper

Colophon Books, 1963). On the Auden gang, books which have helped to consolidate the narrative of a

'Red Decade' include Samuel Hynes, The Auden Generation: Literature and Politics in England in the 1930s

(London: Faber \& Faber, 1976) and Valentine Cunningham, British Writers of the Nineteen-Thirties

(Oxford University Press, 1988)

2 Arthur Koestler, 'Arthur Koestler' in Crossman (ed.), The God that Failed, p.23

${ }^{3}$ Hannah Arendt, 'The Ex-Communists' in Essays in Understanding: 1930-1954, ed. Jerome (New York, NY: Schocken Books, 1994) pp.391-400, p.393

${ }^{4}$ Doris Lessing, Walking in the Shade: Volume Two of my Autobiography, 1949 to 1952 (New York, NY: Harper Perennial, 1998) p.57

${ }^{5}$ Doris Lessing, 'The Small Personal Voice' in A Small Personal Voice: Essays, Reviews, Interviews (London: Flamingo, 1994) pp.7-25, p.18

${ }^{6}$ Doris Lessing, The Golden Notebook (London: Harper Perennial, 2007) p.88

${ }^{7}$ Doris Lessing to John Whitehorn, 17/1/1945 [typescript]. Doris Lessing Archive, British Archive for

Contemporary Writing (hereafter BACW), University of East Anglia, DL/WHI/009, p.1

${ }^{8}$ Doris Lessing, Under my Skin: Volume One of my Autobiography (London: Fourth Estate, 1995) p.312. In

The Golden Notebook, Lessing transfers their fictional equivalents from Cambridge to Oxford, where ' $\mathrm{t}$ ]hey had been in a loose group of about twenty, all vaguely left-wing, vaguely literary, all having affairs with each other in every kind of sexual combination.' pp.86-7

${ }^{9}$ Lessing to Whitehorn, ?/3/1945. BACW, DL/WHI/018, p.3

${ }^{10}$ Ibid., p.3

${ }^{11}$ Doris Lessing, The Golden Notebook (London: Harper Perennial, 2007) p.82

${ }^{12}$ Lessing to Whitehorn, 15/8/1945. BACW, DL/WHI/035, p.1.

${ }^{13}$ Doris Lessing, A Ripple from the Storm (London: Flamingo, 1993) p.73

${ }^{14}$ Adam Guy, 'Early Lessing, Commitment, the World' in Kevin Brazil, David Sergeant and Tom

Sperlinger (eds.), Doris Lessing and the Forming of History (Edinburgh: Edinburgh University Press, 2017) pp.10-25, p.11

${ }^{15}$ Ben Harker, 'Politics and Letters: The 'Soviet Literary Controversy' in Britain' in Literature and History Vol.24 No.2 (Special Issue: Literatures of Anti-Communism ed. by Benjamin Kohlmann and Matthew Taunton) 2015. pp.41-56 (pp.42-3). Raymond Williams's engagement with the Controversy is also explored in John Higgins, Raymond Williams: Literature, Marxism and Cultural Materialism (London: Routledge, 1999) pp.12-14

${ }^{16}$ Doris Lessing to Leonard Smith, 7/10/1947. Doris Lessing Papers, The Keep, University of Sussex, SxMs62/2/82

${ }^{17}$ Unsigned, 'Excerpts from a Review of Zoshchenko's "Before Sunrise" in the "Bolshevik" (No.2, January, 1944)' in The Modern Quarterly, Vo.2 No.1, pp.74-5, p.74

${ }^{18}$ Lessing to Smith, 14/5/1947. The Keep, Sussex, SxMs62/2/72

${ }^{19}$ See John Connor, 'Anglo-Soviet Literary Relations in the Long 1930s' in Benjamin Kohlmann and Matthew Taunton (eds.), A History of 1930s British Literature (Cambridge: Cambridge University Press, 2019) pp.317-30, especially pp.321-2

${ }^{20}$ John Lewis, 'Editorial' in The Modern Quarterly, Vol.2 No.1 (Winter 1946-7) pp.3-15, p.11

${ }^{21}$ Doris Lessing to Coll Macdonald, 3/5/1945. BACW, DL/WHI/026, p.8

22 Ibid. p.6

${ }^{23}$ Harker, 'Politics and Letters', p. 54

${ }^{24}$ Lessing to Smith, 7/10/1947. The Keep, Sussex, SxMs62/2/82, p.3

${ }^{25}$ Doris Lessing to Naomi Mitchison, 15/1/1985 [typescript]. BACW, DL/2008/MITCHISON/2 p.1

${ }^{26}$ Doris Lessing to Paul Gillen, 1/5/95 [typescript]. Doris Lessing Archive, A-Z Correspondence/Gillen, P.. BACW

${ }^{27}$ Lessing to Leonard Smith, 25/9/[1954?]. The Keep, Sussex, SxMs62/2/132. 
${ }^{28}$ Jack Lindsay, The Fullness of Life: Autobiography of an Idea (an edited transcript of the scanned pages, reviewed by reference to the original manuscript.) ed. Anne Cranny-Francis, Chapter 8, p.5

[https://jacklindsayproject.com/the-fullness-of-life/ Accessed 13/2/19]

${ }^{29}$ Jack Lindsay, The Fullness of Life, Chapter 6, pp.26-7

${ }^{30}$ Lukács's distinction between intensive and extensive totalities shows that unlike Lindsay here he did not assert art's responsibility for a comprehensive depiction of all social relations. See Georg Lukács (trans.

Arthur Kahn), 'Art and Objective Truth' in Writer and Critic and Other Essays (London: Merlin Press, 1978), pp.25-60 (p.38). Lessing is likely to have read Lukács during her time in the CPGB writers' group-she certainly read Christopher Caudwell in the 40s. 'They are very very good' she writes to Smithie of Caudwell's Studies in a Dying Culture. Lessing to Smith, 29/12/1947. The Keep, Sussex, SxMs62/2/93, p.4 31 'Resolution of the Central Committee of the Communist Party of the Soviet Union, August 14th 1946 ', in Modern Quarterly 2/1 (Winter 1946-7) pp.75-6, 75

${ }^{32}$ Doris Lessing, 'The Small Personal Voice' in A Small Personal Voice: Essays, Reviews, Interviews (London: Flamingo, 1994) pp.7-25, p.15. Georg Lukács, 'The Ideology of Modernism’ in The Meaning of Contemporary Realism, trans. John and Necke Mander (London: Merlin, 1963), 17-46

33 Marina MacKay, Ian Watt: The Novel and the Wartime Critic (Oxford: Oxford University Press, 2018) pp.156-9

${ }^{34}$ Lessing, 'The Small Personal Voice', p.9

${ }^{35}$ Doris Lessing to John Whitehorn, 17/1/1945. BACW, DL/WHI/009, p.4

${ }^{36}$ Doris Lessing, Under My Skin: Volume One of My Autobiography, to 1949 (London: Harper Perennial, 1995) pp.275-6

${ }^{37}$ Doris Lessing, Landlocked (London: Flamingo, 1993) pp.340-1

${ }^{38}$ Lessing to Smith, 9/3/1965. The Keep, Sussex, SxMs62/2/144.

39 Arendt, On Revolution, p.59

${ }^{40}$ Lessing, Under My Skin, p.275

${ }^{41}$ Reinhart Koselleck, 'Sediments of Time' in Sediments of Time: On Possible Histories, ed. and trans. Sean Franzel and Stefan-Ludwig Hoffmann (Stanford, CA: Stanford University Press, 2018) pp.3-9 (pp.3-4)

${ }^{42}$ Koselleck, 'Sediments', p.5

${ }^{43}$ Koselleck, 'Sediments', p.9

${ }^{44}$ Lessing, A Ripple, p.43

${ }^{45}$ Bertolt Brecht (trans. John Willett), The Decision, in Collected Plays: Three (London: Methuen, 1997), p.63.

${ }^{46}$ Lessing, A Ripple, p.53

47 A google books search reveals just how widespread the quotation, misquotation and misattribution of this passage is. This can be viewed at

https:/ /www.google.co.uk/search?tbm=bks\&hl=en\&q=\%22seared + with + the + shame + of $+a+$ cowardly + and + trivial + past $\% 22$.

${ }^{48}$ Jawaharlal Nehru, The Discovery of India (London: Meridian Books, 1946) p.488

${ }^{49}$ The only earlier use of this exact translation that I can find is in the Woodworkers, Painters and

Buildingworkers Journal from 1944.

https:/ / books.google.co.uk/books?id=s8MuAQAAIAAJ\&q=\%22seared + with + the + shame + of + a + cowa rdly + and + trivial + past $\% 22 \& d q=\% 22$ seared + with + the + shame + of + a + cowardly + and + trivial + past $\% 22 \&$ $\mathrm{hl}=$ en\&sa $=$ X\&ved $=0$ ahUKEwjm2ejArfXhAhVXVBUIHWk4D7A4FBDoAQgxMAI

${ }^{50}$ Brian Cummings, The Book of Common Prayer: A Very Short Introduction (Oxford: Oxford University Press, 2018)

51 Walter J. Ong, Orality and Literacy: The Technologizing of the Word (London: Routledge, 1995) pp.38-9

${ }^{52}$ Lessing, The Golden Notebook, p. 90

${ }^{53}$ Lessing to Whitehorn, 15/8/1945. BACW, DL/WHI/035, p.3

${ }^{54}$ Ibid., p.3

55 Ibid., p. 8

${ }^{56}$ Lessing to Whitehorn, 27/8/1945. BACW, DL/WHI/036, p.1

${ }^{57}$ Lessing to Smith, 04/12/1945 - 13/12/1945. The Keep, Sussex, SxMs62/2/31, p.8

58 Ibid., p.8

${ }^{59}$ Ibid., p.7

${ }^{60}$ Lessing to Smith, 15/10/1947. The Keep, Sussex, SxMs62/2/83, pp.1-2

${ }^{61}$ Ibid., p.1

${ }^{62}$ Lessing to Whitehorn, 24/2/1948. BACW, DL/WHI/81, p.2 
${ }^{63}$ Lessing, Landlocked, p.41

${ }^{64}$ Ibid., p.41

${ }^{65}$ Lessing The Golden Notebook, p.153

${ }^{66}$ Lessing, The Golden Notebook, p.156

${ }^{67}$ Lessing, The Golden Notebook, p.63

${ }^{68}$ Fredric Jameson, Postmodernism, or, The Cultural Logic of Late Capitalism (Durham, NC: Duke University Press, 1991) p.17

${ }^{69}$ Lessing, Landlocked, p.41

${ }^{70}$ Lessing, 'The Small Personal Voice', p.18 